\title{
The Untapped Area Potential for Photovoltaic Power in the European Union
}

\author{
Arnulf Jäger-Waldau $\mathbb{D}$ \\ European Commission, Joint Research Centre (JRC), 21027 Ispra, Italy; arnulf.jaeger-waldau@ec.europa.eu
}

Received: 7 September 2020; Accepted: 27 September 2020; Published: 16 October 2020

\begin{abstract}
The political goal of the European Union is to transform into a prosperous, modern, competitive and climate-neutral economy by 2050. To accelerate this transition, the European Commission has presented a European Green Deal in 2019. The aim is to reduce up to $55 \%$ the greenhouse gas emissions by 2030. The paper looks at the role photovoltaic electricity generation can play to achieve this and whether the required areas for the installation of the photovoltaicaic power needed are available. Following a review of the existing literature, the paper concludes that better use of the technology that has been largely neglected so far coupled with dual-use options would generate much more PV capacity than required to achieve a neutral economy.
\end{abstract}

Keywords: greenhouse gas (GHG) reduction; power sector; photovoltaics; self-consumption; area requirements; dual-use of infrastructure

\section{Introduction}

The analysis document supporting the European Commission Communication "A European long-term strategic vision for a prosperous, modern, competitive and climate-neutral economy" [1] highlights the role of solar photovoltaic power generation as one of the pillars to decarbonise the European Union's (EU) power supply. Market growth and technology progress have made photovoltaics (PV) one of the most cost-effective generation technologies. Over the past years, an increasing number of European Union Member States have introduced auctions for solar power. This trend has led to a decrease in the price levels for PV generated electricity, which currently average between EUR 35 and 70/MWh across the European Union. The lowest bid in the second Portuguese auction in August 2020 was EUR 11.14/MWh almost 25\% less than the 14.76/MWh from the first auction in July 2019 [2]. The total capacity of the auction was $670 \mathrm{MW}$, and projects with a combined capacity of 483 MW include storage. These projects have to be realised by the end of June 2024. The number of solar photovoltaic power plants, including some with storage [3], built without any subsidy is growing every year in more and more countries. With the current industry upscaling and cost reduction in the battery sector, residential PV systems with storage will follow very soon and provide electricity at costs below retail prices not only in single markets.

\section{Policy Background}

Over 20 years ago, the European Council and the European Parliament adopted the "White Paper for a Community Strategy and Action Plan" [4]. The Union's aim at that time was to double the share of renewable energy in the overall gross internal energy consumption, which accounted for 6\% in 1996 to $12 \%$ by 2010 . The level of ambition gradually increased over time, but the huge resource potential of renewable energy in general and photovoltaics in particular still has not yet been tapped [5].

In December 2019, during the conference of parties (COP) 25, the EU Commission president Ursula von der Leyen presented her agenda for a faster greenhouse gas (GHG) emission reduction in 
the European Union "A European Green Deal" [6]. Compared to the 40\% GHG reduction target of the Renewable Energy Directive (RED II) from 2018 [7], the Green Deal calls for up to a 55\% reduction by 2030 relative to 1990. The Green Deal aims at climate-neutrality in the EU by 2050, ensure a just and inclusive transition, as well as design measures to help European companies to become world leaders in clean products and technologies.

In January 2020, the European Commission presented its plan to finance the Green Deal and mobilise EUR 1 trillion of sustainable investments over the next decade [8]. The next step was the proposal for a European Climate Law in March 2020 [9]. The European Parliaments rapporteur for the Climate Law, Jytte Guteland, stated in April 2020 that she would back a 65\% emission reduction target, in line with the UN emission gap report from November 2019 [10].

To counter the economic consequences of the COVID-19 lockdown, a EUR 750 billion recovery fund was agreed on by the European Council on 21 July 2020 [11]. The budget is now being discussed in the European Parliament for approval. This fund aims to set the EU firmly on the path to a sustainable and resilient recovery, creating jobs and repairing the immediate damage caused by the COVID-19 pandemic. At the same time, the fund should support the Union's green and digital priorities. As a next step, the Member States have to prepare national recovery and resilience plans to be examined by the European Commission. In these plans, the Member States are required to outline their individual reform and investment agenda for the years 2021-2023.

\section{Status of Photovoltaics in the EU}

Since the introduction of the first European Renewable Energy Directive in April 2009, the total installed solar photovoltaic power capacity in the European Union (EU27) and the United Kingdom had increased more than 10-fold from 11.3 GW at the end of 2008 to over $134 \mathrm{GW}$ at the end of 2019 (Figure 1) [12,13]. Residential and commercial rooftop installations represented about $60 \%$ of this capacity. In a worldwide comparison, the European Union and the United Kingdom had about $21 \%$ of the cumulative installed capacity of 635 GW at the end of 2019 [14].

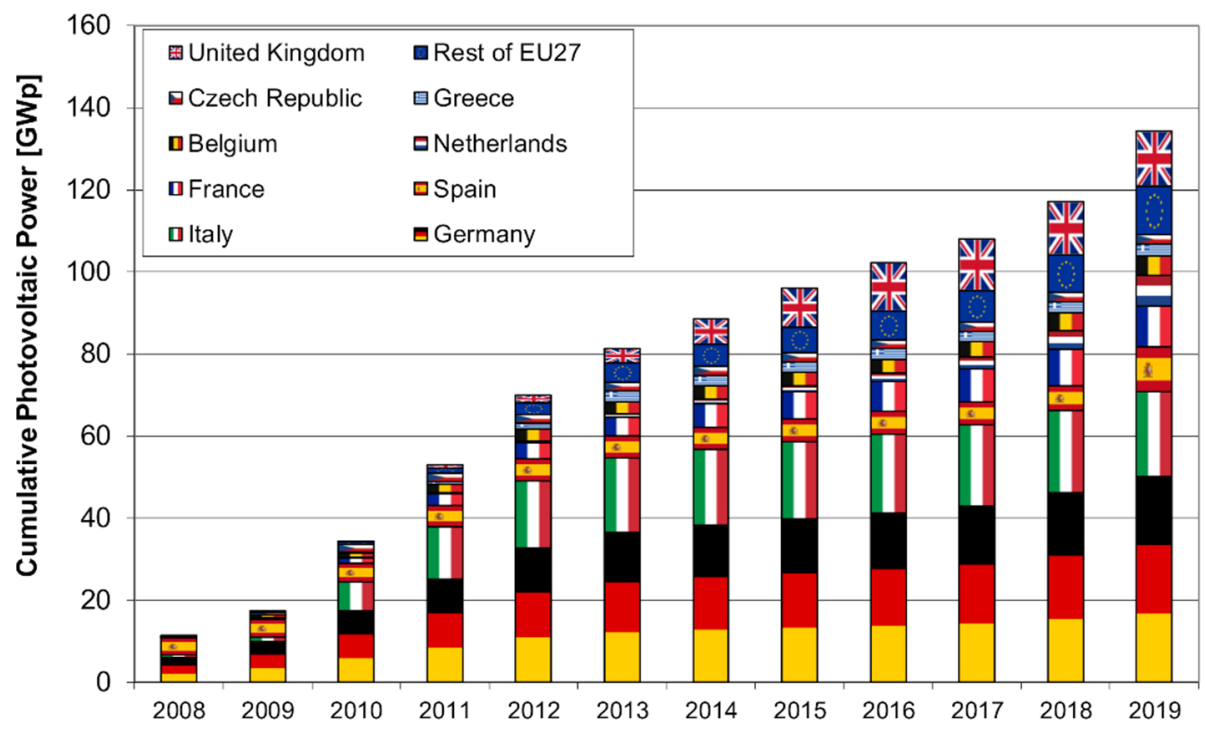

Figure 1. Grid-connected PV capacity in the EU and the United Kingdom [12,13].

The role of photovoltaics for a 55\% GHG reduction by 2030 was analysed in a recent Joint Research Centre (JRC) study [15]. The basis of the study were mainly the politically agreed long-term strategy (LTS) options for 2050 [1] and resulted in a PV capacity range between 450 and 605 GWp by 2030. Under the assumption of more rapid electrification of the tertiary, as well as the transport sector, the required capacity needed could increase to $1.2 \mathrm{TWp}$ in the European Union (EU27). This capacity is close to the requirement needed to realise a 100\% renewable energy supply for Europe by 2050 [16]. 


\section{The Potential of Where to Install Photovoltaics in the EU}

One of the first questions, when looking at these capacity numbers, is: Where could these capacities be installed and would space limitations make it possible?

Over the years, an increasing number of potential analysis has been conducted in various countries and regions [17-20]. The aforementioned obstacles for the installation of PV capacities are related to the current commercial availability of land, as well as land-use policies. The integration of variable solar electricity into the electricity system is another category. However, there are several untapped areas where PV systems can be installed with a significant potential to generate renewable and sustainable electricity.

\subsection{Rooftops}

PV systems on rooftops do not occupy productive land, and their integration into the electricity system is relatively easier, due to their proximity to the point of consumption. The utilisation of solar PV electricity on rooftops also improves the overall efficiency of the energy system. The reason is that no transformation losses occur, unlike in thermal power plants. In 2018, the transformation losses attributed to electricity generation and the heat sector were $3639 \mathrm{TWh}$ or $48 \%$ of the primary energy input [21]. In addition, the electricity distribution system adds another 209 TWh of losses. The current rooftop potential, calculated under conservative conditions, of at least $560 \mathrm{GW}$ is capable of generating 680 TWh of electricity per year [19]. This is already almost half of PV capacity in the high case scenario mentioned before. A substantial part of this capacity has to be installed by citizens, either on their individual house rooftops or as co-owned systems on multi-apartment buildings. The interest for solar electricity generation with and without storage for self-consumption, as well as systems on apartment buildings, is gradually increasing [22,23]. Once the recast of the Energy Performance of Building Directive including the concept of Nearly Zero-Energy Buildings (NZEBs) is adopted by the Member States in national legislation, an additional PV rooftop potential will be created [24]. In addition, several municipalities are currently discussing, or have already introduced, mandatory requirements to install renewable energy systems in new buildings. If only $4 \mathrm{kWp}$ are added to each of the 1.5 million new buildings constructed in the EU every year, an additional $6 \mathrm{GWp}$ would be added every year. By 2030 , this would translate to an additional $60 \mathrm{GWp}$.

If the rooftop potential on existing and new buildings were utilised until 2030, between 485 and $545 \mathrm{GWp}$ of PV systems would have to be installed. Such an installation wave would create a large number of local jobs in the installation business. Despite the fact that the quantification of jobs for the installation of rooftop PV systems is more complex than for large PV systems, the 3.5 full-time work equivalent (FTE) per MW of the USA Solar Census 2018 were used as a lower bound benchmark to calculate the number of jobs [25]. Within the next ten years, it is expected that the FTE will decrease to 2.5 FTE per MW. Under these assumptions, the utilisation of the rooftop potential could provide between 190,000 and 225,000 jobs in 2030. These numbers are close to those of a detailed study about the importance of PV power to create new jobs [26].

\subsection{Coal Mining Regions}

The need to decarbonise the EU and the United Kingdom power sector has far-reaching consequences for the 42 regions, where coal and lignite are still mined and used for power generation. Despite the plans to close down coal mining and use in thermal power plants, this sector still accounts for a significant economic activity [27]. The sector still provides about 240,000 jobs in coal and lignite mining $(180,000$ jobs $)$ and in power plants operation and maintenance $(60,000$ jobs $)$. It is imperative to find socially acceptable job alternatives for those employees.

The installation of PV power systems on the sites of closed mines and the surrounding area has many advantages. First, it enables the redevelopment of the brownfields in an integrated manner; it does not require extra environmental permitting, and it generates cash flow for the landowner [28]. 
Second, the technical potential for solar photovoltaic power on the mines and surrounding land in these 42 regions was estimated at $580 \mathrm{GW}$ [29]. Installing larger solar PV plants in parallel with the closure of mines and power stations over the next 15 years would provide about 135,000 jobs annually for the construction of PV plants. The installation of these PV systems will benefit from dedicated financial instruments like the Just Transition Fund, as well as the recent agreed COVID-19 Recovery Fund [11,30]. The number of operation and maintenance (O\&M) jobs could grow to 50,000 in the same time span, even if the number of O\&M jobs per MW halved, due to automation and digitalisation. However, as mentioned before, rooftop PV installations would bring about the opportunity of additional jobs.

\subsection{Dual-Use of Infrastructure}

The dual-use of infrastructure, examples given below, offers additional potentials: To install PV power systems often close to the place of electricity use, as well as to avoid the use of open land. So far, the analysis of these potentials is still in its infancy, but first case studies have already been conducted. In many instances, these applications provide not only electricity close to where it is consumed, but offer additional advantages. More detailed potential analyses are still needed to quantify the total potential. Some examples:

- Agricultural photovoltaics (Agri-PV): Agri-PV offers the possibility to optimise the use of agricultural land, increase agricultural yields and generate electricity, which can either be used locally or sold for extra revenue [31,32];

- Closed landfill sites: First, landfills are brownfields, and their use for PV plants will not affect sensitive ecosystems [28]. Second, closed landfills are often connected to the electricity grid, and in the case of landfill gas use, the PV system can improve the load factor of the plant;

- Façades with PV of buildings: PV Façades on buildings can reduce the heat load in the building and reduce the power needed for cooling [33,34];

- Hydro dams: In the case of earthen dams, the PV installation can protect the surface and minimise erosion caused by rain [35];

- Irrigation channels and floating PV: Both applications can help reduce water evaporation, which, especially in arid regions, is of substantial importance [36,37];

- Parking lots: Covering parking lots with PV canopies enables sustainable electricity generation to charge electric vehicles and provides shading for the automobiles [38,39];

- Sound barriers: Sound barriers along motorways and train lines can be used to generate electricity not only when they are south facing; thanks to bifacial PV technology, east- and west-facing barriers can also be utilised $[40,41]$. The electricity generated along train lines could be used directly to power trains. In contrast, sound barriers on motorways could provide sustainable electricity either to the municipalities they are shielding the noise from or to electric vehicle charging stations in service areas.

\section{Conclusions}

To fully utilise these untapped potentials and realise a sustainable energy transition will require additional adaptation measures in the power sector due to the variable nature of solar photovoltaic electricity generation. The combination of PV with other renewable energy sources, different storage options, demand management and sector coupling are some examples. However, this paper is not about the energy transition, but what potential exists to install PV systems on yet not used areas.

The European Union is currently the largest political block, which has political targets in place to establish a climate-neutral economy by 2050. The analysis of existing studies reveals that the currently unused technical potentials on rooftops in coal mining regions and the dual-use of existing infrastructure could provide more electricity from PV power systems than is needed to achieve the political goal. PV installations on rooftops and brownfield of coal mining regions are sufficient to install at least 1.2 TWp of PV power, without disrupting open land. Exploiting the mostly unused 
PV potential to make a dual-use of existing agricultural, traffic, and urban infrastructure can increase capacity. However, to quantify this technical potential, more future analysis is needed.

Funding: This research received no external funding.

Conflicts of Interest: The authors declare no conflict of interest. The scientific output expressed is based on the current information available to the author, and does not imply a policy position of the European Commission.

\section{References}

1. In Depth Analysis in Support of the Commission Communication COM. 773 A Clean Planet for All-A European Long-Term Strategic Vision for a Prosperous, Modern, Competitive and Climate Neutral Economy; European Commission: Brussels, Belgium, 2018.

2. Rebública Porugesa, XXII Governo, Novo Leilão Solar Garante Poupança Anual de 37,2 Milhões Aos Consumidores. 26 August 2020. Available online: https://www.portugal.gov.pt/pt/gc22/comunicacao/ noticia?i=novo-leilao-solar-garante-poupanca-anual-de-372-milhoes-aos-consumidores (accessed on 31 August 2020).

3. St John, J.; Greentechmedia, L.A. Looks to Break Price Records with Massive Solar-Battery Project. 1 July 2019. Available online: https://www.greentechmedia.com/articles/read/ladwp-plans-to-break-new-lowprice-records-with-massive-solar-battery-proje\#gs.0kbm0m (accessed on 31 August 2020).

4. Energy for the Future: Renewable Sources of Energy - White Paper for a Community Strategy and Action Plan, COM(97)599 Final (26/11/1997). Available online: http://europa.eu.int/comm/energy/library/599fi_en.pdf (accessed on 31 August 2020).

5. Jäger-Waldau, A.; Scholz, H. EU renewables: Energy end-use efficiency and electricity from biomass, wind and PV in the EU. Refocus 2005, 6, 58-60. [CrossRef]

6. European Commission Communication. The European Green Deal; COM (2019) 640 final; European Commission: Brussels, Belgium, 11 December 2019.

7. Directive (EU) 2018/2001 of the European Parliament and of the Council of 11 December 2018 on the promotion of the use of energy from renewable sources (recast). Off. J. Eur. Union 2018, L 328/82.

8. European Commission Communication. Sustainable Europe Investment Plan-European Green Deal Investment Plan; COM (2020) 21final; European Commission: Brussels, Belgium, 14 January 2020.

9. European Commission. Commission Proposal for a Regulation: European Climate Law; European Commission: Brussels, Belgium, 2020.

10. United Nations Environment Programme. Emissions Gap Report 2019; UNEP: Nairobi, Kenya, 2019; ISBN 978-92-807-3766-0.

11. European Council. EUCO 10/20. 21 July 2020. Available online: https://www.consilium.europa.eu/media/ 45109/210720-euco-final-conclusions-en.pdf (accessed on 31 August 2020).

12. Szabó, S.; Jäger-Waldau, A.; Szabó, L. Risk adjusted financial costs of photovoltaics. Energy Policy 2010, 38, 3807-3819. [CrossRef]

13. Jäger-Waldau, A. Snapshot of photovoltaics-February 2020. Energies 2020, 13, 930. [CrossRef]

14. Masson, G.; Kaizuka, I.; Lindahl, J.; Jaeger-Waldau, A.; Neubourg, G.; Donoso, J.; Tilli, F. A Snapshot of Global PV Markets-The Latest Survey Results on PV Markets and Policies from the IEA PVPS Programme in 2018. In Proceedings of the 2019 IEEE 46th Photovoltaic Specialists Conference (PVSC), Chicago, IL, USA, 16-21 June 2019; pp. 588-591. [CrossRef]

15. Jäger-Waldau, A.; Kougias, I.; Taylor, N.; Thiel, C. How photovoltaics can contribute to GHG emission reductions of 55\% in the EU by 2030. Renew. Sustain. Energy Rev. 2020, 126, 109836. [CrossRef]

16. SolarPower Europe and LUT University. 100\% Renewable Europe: How to Make Europe's Energy System Climate-Neutral Before 2050; SolarPower Europe: Brussels, Belgium, 2020.

17. Zhang, Y.; Ren, J.; Pu, Y.; Wang, P. Solar energy potential assessment: A framework to integrate geographic, technological, and economic indices for a potential analysis. Renew. Energy 2020, 149, 577-586. [CrossRef]

18. Lobaccaro, G.; Lisowska, M.M.; Saretta, E.; Bonomo, P.; Frontini, F. A Methodological Analysis Approach to Assess Solar Energy Potential at the Neighborhood Scale. Energies 2019, 12, 3554. [CrossRef]

19. Bódis, K.; Kougias, I.; Jäger-Waldau, A.; Taylor, N.; Szabó, S. A high-resolution geospatial assessment of the rooftop solar photovoltaic potential in the European Union. Renew. Sustain. Energy Rev. 2019, 114. [CrossRef] 
20. Pinna, A.; Massidda, L. A Procedure for Complete Census Estimation of Rooftop Photovoltaic Potential in Urban Areas. Smart Cities 2020, 3, 873-893. [CrossRef]

21. Eurostat, Energy Balances. Available online: https://ec.europa.eu/eurostat/data/database (accessed on 31 August 2020).

22. Keiner, D.; Ram, M.; Barbosa, L.D.S.N.S.; Bogdanov, D.; Breyer, C. Cost optimal self-consumption of PV prosumers with stationary batteries, heat pumps, thermal energy storage and electric vehicles across the world up to 2050. Sol. Energy 2019, 185, 406-423. [CrossRef]

23. Jäger-Waldau, A.; Adinolfi, G.; Batlle, A.; Braun, M.; Bucher, C.H.; Detollenaere, A.; Frederiksen, K.H.B.; Graditi, G.; Guerrero Lemus, R.; Lindahl, J.; et al. Self-consumption of electricity produced with photovoltaic systems in apartment buildings-Update of the situation in various IEA PVPS countries. In Proceedings of the IEEE PVSC-47, Virtual Meeting, 15 June-21 August 2020.

24. Directive (EU) 2018/844 of the European Parliament and of the Council of 30 May 2018 amending Directive 2010/31/EU on the energy performance of buildings and Directive 2012/27/EU on energy efficiency. Off. J. Eur. Union 2018, 156/75.

25. Alves Dias, P.; Kanellopoulos, K.; Medarac, H.; Kapetaki, Z.; Miranda-Barbosa, E.; Shortall, R.; Czako, V.; Telsnig, T.; Vazquez-Hernandez, C.; Lacal Arántegui, R.; et al. EU Coal Regions: Opportunities and Challenges Ahead; Publication Office of the European Union: Luxembourg, 2018. [CrossRef]

26. Solar Energy Industries Association (SEIA). U.S. Solar Market Insight Report-2018 Year in Review; Solar Energy Industries Association (SEIA): Washington, DC, USA, 2019.

27. Fragkos, P.; Paroussos, L. Employment creation in EU related to renewables expansion. Appl. Energy 2018, 230, 935-945. [CrossRef]

28. Szabó, S.; Bódis, K.; Kougias, I.; Moner-Girona, M.; Jäger-Waldau, A.; Barton, G.; Szabó, L. A methodology for maximizing the benefits of solar landfills on closed sites. Renew. Sustain. Energy Rev. 2017, 76, 1291-1300. [CrossRef]

29. Bódis, K.; Kougias, I.; Taylor, N.; Jäger-Waldau, A. Solar photovoltaic electricity generation: A lifeline for the european coal regions in transition. Sustainability 2019, 11, 3703. [CrossRef]

30. European Commission. Regulation Establishing the Just Transition Fund; COM (2020) 22 Final, 2020/0006 (COD); European Parliament and the Council: Brussels, Belgium, 2020.

31. Dinesh, H.; Pearce, J.M. The potential of agrivoltaic systems. Renew. Sustain. Energy Rev. 2016, 54, $299-308$. [CrossRef]

32. APV-RESOLA. Available online: https://www.agrophotovoltaik.de/english/research-project-apv-resola/ (accessed on 27 August 2020).

33. Defaix, P.R.; van Sark, W.G.J.H.M.; Worrell, E.; de Visser, E. Technical potential for photovoltaics on buildings in the EU-27. Sol. Energy 2012, 86, 2644-2653. [CrossRef]

34. El Gammal, A.; Mueller, D.; Buerkstuemmer, H.; Vignal, R.; Macé, P. Technical Evaluation of BIPV Power Generation Potential in EU-28. In Proceedings of the 32nd European Photovoltaic Solar Energy Conference and Exhibition, Munich, Germany, 21-26 June 2016. [CrossRef]

35. Kougias, I.; Bódis, K.; Jäger-Waldau, A.; Monforti-Ferrario, F.; Szabõ, S. Exploiting existing dams for solar PV system installations. Prog. Photovolt. Res. Appl. 2016, 24, 229-239. [CrossRef]

36. Gaikwad, O.D.; Deshpande, U.L. Evaporation control using floating pv system and canal roof top solar system. IRJET 2017, 4, 214-216.

37. Kougias, I.; Bódis, B.; Jäger-Waldau, A.; Moner-Girona, M.; Monforti-Ferrario, F.; Ossenbrink, H.; Szabó, S. The potential of water infrastructure to accommodate solar pv systems in mediterranean islands. Sol. Energy 2016, 136, 174-182. [CrossRef]

38. Neumann, H.-M.; Schär, D.; Baumgartner, F. The potential of photovoltaic carports to cover the energy demand of road passenger transport. Prog. Photovolt. Res. Appl. 2012, 20, 639-649. [CrossRef]

39. Krishnan, R.; Haselhuhn, A.; Pearce, J.M. Technical solar photovoltaic potential of scaled parking lot canopies: A case study of walmart USA. J. Innov. Sustain. RISUS 2017, 8, 104-125. [CrossRef] 
40. Nordmann, T.; Vontobel, T.; Clavadetscher, L. 15 Years of Practical Experience in Development and Improvement of Bifacial Photovoltaic Noise Barriers along Highways and Railway Lines in Switzerland. In Proceedings of the 27th European PV Conference and Exhibition, Frankfurt, Germany, 24-28 September 2012. [CrossRef]

41. Faturrochman, G.J.; de Jong, M.M.; Santbergen, R.; Folkerts, W.; Zeman, M.; Smets, A.H.M. Maximizing annual yield of bifacial photovoltaic noise barriers. Solar Energy 2018, 162, 300-305. [CrossRef]

Publisher's Note: MDPI stays neutral with regard to jurisdictional claims in published maps and institutional affiliations.

(C) 2020 by the author. Licensee MDPI, Basel, Switzerland. This article is an open access article distributed under the terms and conditions of the Creative Commons Attribution (CC BY) license (http://creativecommons.org/licenses/by/4.0/). 